\title{
Clinical Influence of Triple Omega Fatty Acids (Omega-3, 6, 9)
}

\author{
Walaa Fikry Elbossaty* \\ Department of Chemistry,Biochemistry division, Damietta University, Egypt
}

Received: 漹 June 25, 2018 Published: 眥July 10, 2018

*Corresponding author: WalaaFirkyElbossaty, Department of Chemistry, Biochemistry Divisoin, Faculty of Science, Damietta University, Egypt

\begin{abstract}
Fatty acids play bio vital role in biological life, one of the most important fatty acid triple omega. These fatty acids are un saturation fatty acids, two from them are essential where the body cannot able to synthesis them (omega 3, and 6), while the other is essential fatty acid the body can synthesis it but this need adequate amount from omega 3, and 6. Each type of omega fatty acids has own chemical structure, sources, and functions. Triple omega play essential role in protect the human body from heart attack. It is very necessary to make balance between triple omega dose, the high level lead to deposition of fats in the body, and this lead to several healthy problem.
\end{abstract}

Keywords: Triple Omega; Fatty Acids;Omega-3; Omega-6; Omega-9; Heart Attack

\section{Introduction}

Fatty acids are considering vital biochemical components for all organs of the human body, such as skin, lungs, heart, and brain [1]. Fatty acids are categorized in to two classes according to their chemical structure ,two classes are saturation fatty acids in which the number of hydrogen that are attached to the carbon backbone of these molecules, while the other group un saturation fatty acid , where a few hydrogen missing with double bonds between the carbons where those hydrogen would go. Also, fatty acids can be classified according to the body requirements in to essential fatty acids that your body does not produce on its own, and non-essential fatty acids where the body can produce them [2]. Omega fatty acids are described as unsaturated healthy fats due to them prevent a number of medical problems such as depression, cardiovascular disease, brain dysfunction, asthma and arthritis [3].There are 3 types of omega fatty acids; Omega-3, Omega-6, and Omega-9, each one from them has own chemical structure and biological roles [4]. Omega-3 fatty acid ( $\alpha$-linolenic acid) is an essential fatty acid that plays significant role in brain function and may help in prevention heart attack. The American Heart Association recommends a diet in which fatty fish, like salmon, herring, sardines and tuna are consumed at least twice a week [5].

In addition to their role in the structure and function of cells throughout your body, the omega-3s reduce your of cardiovascular disease through multiple actions. They fight inflammation, keep blood vessels healthy, and reduce levels of cholesterol and triglycerides. They may also help prevent rheumatoid arthritis and cancer, according to the Harvard School of Public Health [6]. The other essential fatty acid is Omega-6 fatty acid (Linoleic
Acid); omega- 6 should be taken about twice as much as omega- 3 ; where omega- 6 to omega-3 ratio is 2:1 [7]. Finally, Omega-9, or monounsaturated oleic and stearic acid, is a non-essential fatty acid which produced naturally by the body in the presence of enough amount of both Omega 3 and 6 fatty acids. In the absence of omega fatty acids 3 , and 6 omega 9 must take from the diet. Natural foods and healthy benefits for triple omega are summarized in the following (Table1) [6].

Table 1: Natural foods\& Biological Benefits for Triple omega.

\begin{tabular}{|c|c|}
\hline Natural foods & Biological Benefits \\
\hline & Omega-3 \\
\hline $\begin{array}{l}\text { a) Salmon } \\
\text { b) Mackerel } \\
\text { c) Eggs } \\
\text { d) Fruits } \\
\text { e) Grains } \\
\text { f) Spirulina } \\
\text { g) Brazil Nuts } \\
\text { h) Mustard Seeds } \\
\text { i) Pumpkin Seeds } \\
\text { j) Chia Seed Oil } \\
\text { k) Wheat Germ Oil } \\
\text { l) Green Leafy } \\
\text { Vegetables }\end{array}$ & $\begin{array}{l}\text { a) Reduce risk of heart attack, through decrease } \\
\text { the level of cholesterol } \\
\text { b) Anti-inflammatory. } \\
\text { c) Lower blood pressure } \\
\text { d) Treatment of various diseases such as, Asthma, } \\
\text { Diabetes, Osteoporosis, Arthritis, and Some } \\
\text { Cancers. }\end{array}$ \\
\hline
\end{tabular}




\begin{tabular}{|c|c|}
\hline \multicolumn{2}{|r|}{ 0mega-6 } \\
\hline $\begin{array}{l}\text { a) Seeds } \\
\text { b) Nuts } \\
\text { c) Grains } \\
\text { d) Green leafy } \\
\text { vegetables } \\
\text { e) Cold vegetable } \\
\text { oils }\end{array}$ & $\begin{array}{l}\text { a) Reduce risk for developing type } 2 \text { diabetes. } \\
\text { b) Reduce the level of cholesterol. } \\
\text { c) Treatment of allergy, and multiple sclerosis. }\end{array}$ \\
\hline \multicolumn{2}{|r|}{ Omega-9 } \\
\hline $\begin{array}{l}\text { a) Almonds } \\
\text { b) Macadamia Nuts } \\
\text { c) Chia Seed Oil } \\
\text { d) Olives \& Olive Oil } \\
\text { e) Avocados } \\
\text { f) Pecans } \\
\text { g) Pistachios } \\
\text { h) Cashews }\end{array}$ & $\begin{array}{l}\text { a) Reduces bad cholesterol (LDL) and increasing } \\
\text { good cholesterol (HDL) in bloodstream. } \\
\text { b) Form myelin sheath as cover to protect nerves. } \\
\text { c) Weight Loss } \\
\text { d) Eye Disorder } \\
\text { e) Heart disease } \\
\text { f) Immune System }\end{array}$ \\
\hline
\end{tabular}

\section{Overdose Side Effects of Triple Omega}

Usually maintains a healthy diet that provides all nutrients. It will keep you away from many diseases [8]. As a result of consumption Omega 369 , this creates unbalance between these nutrients. In line for unbalance of nutrients it creates deposition of those extra fats. These lead to a health problem. These fatty acids must be taken according to the American Heart Association (AHA) as the following doses [7]:

$$
\begin{aligned}
& \text { Omega 3: < } 3 \text { gram / daily } \\
& \text { Omega 6: Less than Omega } 3 \\
& \text { Omega 9: Less than Omega } 6
\end{aligned}
$$

ISSN: 2574-1241

DOI: 10.26717/BJSTR.2018.06.001383

Walaa Fikry Elbossaty. Biomed J Sci \& Tech Res

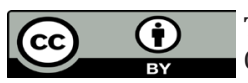

This work is licensed under Creative Commons Attribution 4.0 License

Submission Link: https://biomedres.us/submit-manuscript.php
Some signs can be happen if triple omega take in large dose includes:
a) Skin Rashes or itching
b) Dizziness
c) Swelling of tongue, face or throat
d) Breathing problem

\section{Conflicts of Interest}

The authors declare that they have no conflict of interests.

\section{References}

1. Salem N, Lin Y, Moriguchi T, Lim SY, Salem N, et al. (2015)Distribution of Omega- 6 and Omega-3 Polyunsaturated Fatty Acids in the Whole Rat Body and 25 Compartments.Prostaglandins Leukot Essent Fatty Acids100: 13-20.

2. Carol R (2017) Essential Fatty Acid Deficiency. Practical gastroenterology164:37-44.

3. Giuseppe G, Fabio G, Stefano M, Michele M (2014) Omega-3 Fatty Acids and Depression: Scientific Evidence and Biological Mechanisms. Oxidative Medicine and Cellular Longevity1-16.

4. Ab Latif W, Sajad A, Anjum A (2015) Omega-3 fatty acids and the treatment of depression: a review of scientific evidence.Integr Med Res 4(3): 132-141.

5. Muley P, Shah M, Muley A (2015)Omega-3 Fatty Acids Supplementation in Children to Prevent Asthma: Is It Worth? A Systematic Review and Meta-Analysis. Journal of Allergy 2015: 312052.

6. Ravi K (2015)Emerging Risk Biomarkers in Cardiovascular Diseases and Disorders.Journal of Lipids2015:1-50.

7. Artemis P (2016) An Increase in the Omega-6/Omega-3 Fatty Acid Ratio Increases the Risk for Obesity. Nutrients8(3): 128.

8. Melina V, Craig W, Levin S (2016)Position of the Academy of Nutrition and Dietetics: Vegetarian Diets.Journal of the Academy of Nutrition and Dietetics 116(12): 1970-1980.

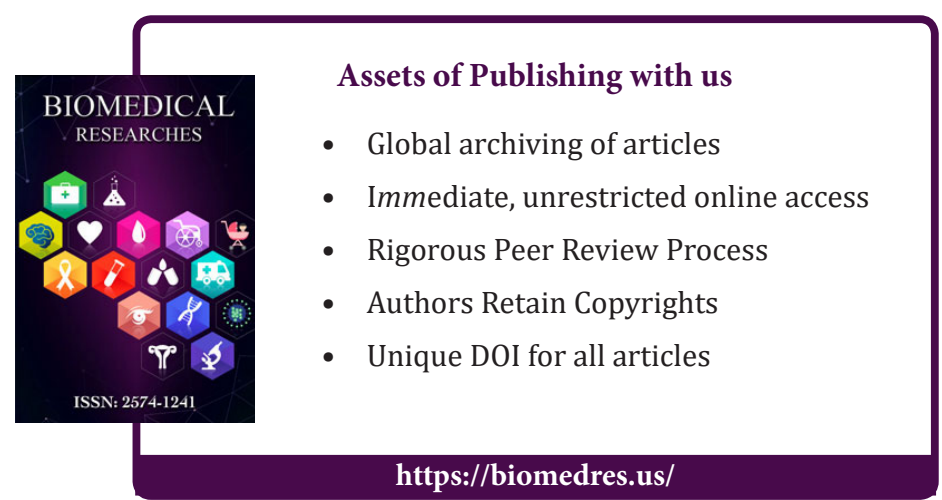

